\title{
An Empirical Study on Task-based Listening Teaching Mode in Junior High School of China
}

\author{
Zeng Ni \\ School of Foreign Languages, China, Three Gorges University, 8 Daxue Road, Yichang City, 443002, Hubei Province, PR, China \\ E-mail: $1260923241 @ q q . c o m$ \\ Liu Jingxia (Corresponding author) \\ School of Foreign Languages, China, Three Gorges University, 8 Daxue Road, Yichang City, 443002, Hubei Province, PR, China \\ E-mail: clare04@126.com
}

Doi:10.7575/aiac.alls.v.8n.2p.202

Received: $18 / 03 / 2017$

URL: http://dx.doi.org/10.7575/aiac.alls.v.8n.2p.202

Accepted: 27/04/2017

This research is financed by Hubei Province Ministry of Education, China and Three Gorges University, China (No. 16D018, and No. SDYC2016127)

\begin{abstract}
Task-based teaching demands that the teacher should first explicitly understand the objectives and then design some proper activities, which are closely relevant to daily life, to involve the students enthusiastically into these activities and improve their English listening competence. Research in task-based listening teaching has distinct significant in teaching theory and practice. The writer of this paper has carried out an experiment in the junior high school listening teaching to test whether students' interest in learning English can be increased and their listening abilities can be improved by Take-based Approach, as well as probing into the best way of employing the theory in English listening teaching. The experiment is a three-month program that involves two junior high school classes with 74 students. One is the experimental class using Task-based Approach in teaching, while the other is the control class using the traditional teaching approach. There are no differences in their listening ability before the experiment. The analysis of the experimental results shows that this model mobilizes students' learning enthusiasm in English study, and over time it can be concluded that the teaching theory is conductive to the improvement of the students' listening level and emotional state.
\end{abstract}

Keywords: English listening teaching; Task-based Approach; Listening ability; Learning interest

\section{Introduction}

In language acquisition, listening is the basis of students' communicative abilities. During the process of English teaching, listening comprehension also plays an essential role in developing students' basic skill in language learning. Thus, it is important for students to improve their listening competence.

Since Task-based teaching was introduced into China in 1997, researchers have focused on applying it to practice in China to construct its local patterns. With an interest in English listening teaching, the writer carried out research to see what we can do to improve students' listening comprehension. In this research,we carry out an experiment of listening teaching to test the effectiveness of Task-based Approach in English listening class, as well as probing into the proper listening teaching modes.

\section{Literature Review}

Listening comprehension is an activity in which we must listen carefully to get information from what we hear (Underwood, 1989:45). No matter what the definition is, in foreign language learning, we know that listening is a complex process. When it comes to listening teaching, the features of listening comprehension require teachers to consider more methods to stimulate students' interest and to conduct students' learning.

The Task-based Approach (TBA) is a best way to achieve those purposes. From Willis (1996:50), the Task-based Approach aims at providing opportunities for learners to learn language through practical experience, that is, the use of tasks. About components of task, Nunan (1989:48) supplies a framework to analyze a task about its components, such as goals, input, activities, teacher's role, student's role and settings. Therefore, that Task-based Approach mainly refers to the way of basing on a behavior rather than a linguistic organization. During the process, learners are attracted to take part in activities to learn language and accumulate skill. Two models of TBA are usually used in teaching process. One is Willis's model (1996), and the other is Skehan's (1998). The former one has three stages: pre-task stage, task cycle and language focus. Based on Willis's model, Skehan (1998) proposes his model which also consists of three stages that are pre-task stage, during-task stage and post-task stage. The pre-task activities have three types: teaching, consciousness raising and planning. In during-task activity, two general aspects are covered: manipulations and 
pedagogical decision. In the last stage, it is most important to teach the learners the way reflected on learning process and elicit their own methods to cope with different learning purposes.

\section{Experimental Design}

\subsection{Hypothesis}

In this experiment, the writer wants to determine the effectiveness of Task-based Approach in English listening teaching in junior high school. The hypothesis in the experiment is that the Task-based approach can enhance students' interest in studying listening and improving their levels of English listening.

\subsection{Subjects}

There are 74 students in Grade 8 from No.5 Middle School of Yichang in Hubei of China in the experimental activity. The whole experiment lasted three months from September 10 to December 9 in 2014. Both classes contain 37 students. Class 2, which has 21 boys and 16 girls, belongs to the experimental group (EG). Class 4 belongs to the control group (CG). This class has 23 boys and 14 girls. The author teaches in both the experimental class and the control class.

\subsection{Instrument}

\subsubsection{Teaching Materials}

Both the experimental group and the control group use the same teaching material, which is Student's Book "Go for it" (2013) for Grade Eight, published by the People's Education Press, China.

\subsubsection{Test}

The pre-test and post-test are given to the two groups at the beginning and the end of the experiment. One is to test whether the English listening levels of the two classes are at the same level, the other is adopted to test whether TBA could play a positive role in English listening class. Each paper, whose total points are 120, contain two parts: the listening part and the writing part. The scores of the listening part are 25 points. Each listening part contains three sections: choosing the correct pictures, listening and choosing the correct answers, listening to the dialogue and writing the correct answers.

\subsubsection{Questionnaire}

The questionnaires are derived from Jiao's (2014). Then, they are redesigned by the author. One (see Appendix I) is for all of them to test their interest and learning skill in English, while the other (see Appendix II) is mainly used in the experimental class to reflect the attitude of the students who are taught by task-based listening teaching. The control group sample answers the first four questions in the second questionnaire.

The pre-questionnaire consists of ten questions. Q1 to Q 4 are related to the attitude towards English listening. Q 5 to Q 8 are about students' listening skill. Q 9 is on students' emotion of listening and Q 10 is related to the use of English in daily life. For each question, there are 3 answers. Except for Question 5, in each question, choosing A represents agreement, answering $\mathrm{B}$ means neutral attitude and choosing $\mathrm{C}$ means disagreement.

The post-questionnaire also consists of ten questions. Q1 to Q 4 remain the same as in the first questionnaire. The last six questions are just to get the effects of the task-based listening teaching.

\subsection{Experimental Procedures}

The experiment mainly consists of three stages: pre-test stage, implementation stage and post-test stage. In order to identify the interest and the listening level of the 74 students, a questionnaire survey (see Appendix I) and a pre-test are conducted on the experimental class and the control class. In the experiment, the only difference between the two classes is the teaching approach. In the implementation stage, the control group (CG) is dominated by the traditional teaching approach, while the experimental group (EG) is taught by the task-based language teaching. In the traditional teaching method, the teacher plays the recorder without indicating the background or the theme description. The students should finish the relevant choices according to what is said on the tape. Finally, the right answers are given to them. For the experimental group, we follow the pre-listening step, the while-listening step and the post-listening step. In the last stage, post-test and post-questionnaire are used to know about whether the Task-based Approach can improve their interest in English listening class and their levels of listening, compared with the traditional teaching method.

The details of listening teaching in the experimental group (EG) can be seen as follows.

\subsubsection{Pre-listening Step}

The pre-listening phase plays a preparatory role in listening teaching, aiming at helping the learners find out the goal of listening and providing the necessary background to eliminate the obstacles in the process of listening.

At the beginning of the listening class, the teacher introduces a relevant discussion about the topic in which the students could communicate their predictions that are supposed to help them predict what they would listen to and make a contribution to activate their passions. Besides, those lead-in tasks with special design also provide opportunities for them to develop confidence to deal with listening problems in a relaxing learning atmosphere. After the discussion, the teacher would put forward some words and phrases related to the listening materials and emphasize the use of them. These activities could combine new knowledge with their daily examples to remove the stress of their mind.

During this stage, there are many activities for communication and expectation. And I divide them into three parts. For teachers, they can give background in formation by a lot of methods like English songs, videos, poems, role-plays and so on. What matters in this part is that what you choose should be suitable for the task. For students, they can prepare 
something relevant to share with classmates. For both of them, teachers can show some pictures for students to discuss and consider how the while-listening activity will be done.

\section{Example: Prediction}

Prediction is meaningful in pre-listening stage. In learning "What's the best movie theater?" (Unit 4 Section A 1a of New Standard English Textbook, Junior English Book for Grade Eight), the teacher shows two pictures of theater in Yichang of Hubei, China to the students and asks them how they choose which movie theater to go to.

With the help of the pictures, it is easy for the students to arouse the enthusiasm and make abundant predictions relevant to the theater such as seats, screens, sound, distance and tickets. It is the real reflection of learning in the life.
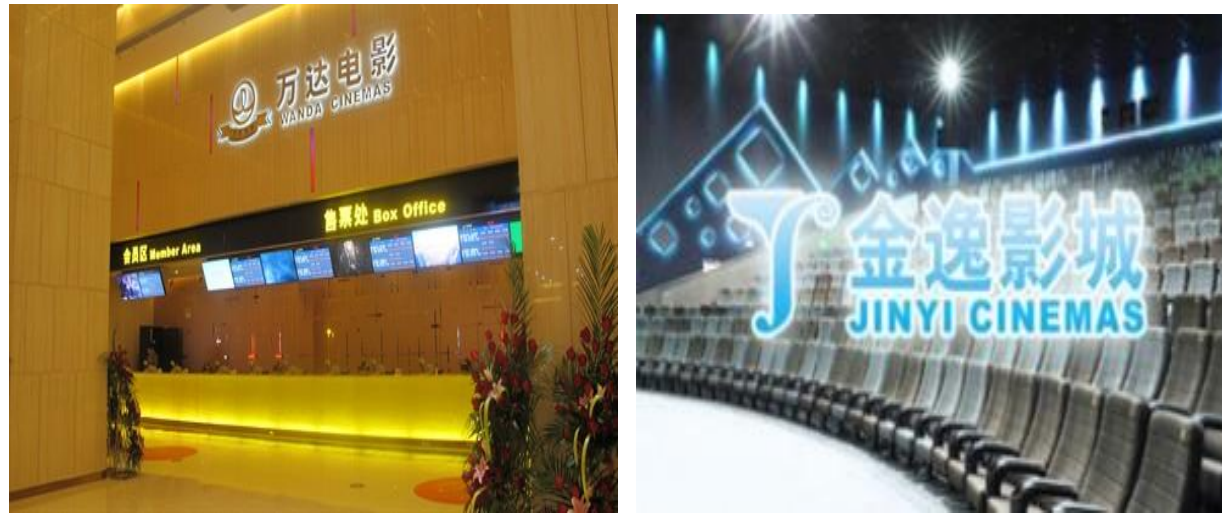

\subsubsection{While-listening Step}

While-listening phase is the process of receiving and understanding of language. This stage is an activity in which students do the exercises and adjust their listening methods under the guidance of the teacher. The main purpose is to train students to capture the key information and then grasp the meaning of the listening materials, but not to catch every word. According to the textbook, the design of activities usually mainly conclude three kinds: numbering the pictures, matching the phrases or words with correct pictures and filling in blank according to the transcript. With the development of educational reformation, English teaching is gradually reflecting the teaching principle of taking the students as the main body. During the listening, teachers should pay more attention to the conduction of listening methods. As the fundamental rule, students have to accept more information from the design, that is to say, reading the questions and the choices of the listening tasks before listening to find the key words of the questions and the choices to help them to listening selectively. What's more, it is necessary to make a prediction properly like in pre-listening phase. But we should know that any prediction must obey to the listening materials. Surely, there are lots of ways to predict like predicting through pictures, contexts, even speaker's mood. There is an example to show specifically.

\section{Example: Predicting through Pictures}

In learning 1c and 1d in Section B of Unit 4 (New Standard English Textbook, Junior English Book for Grade Eight), and the teacher asks students to look at those pictures carefully and answers some questions.
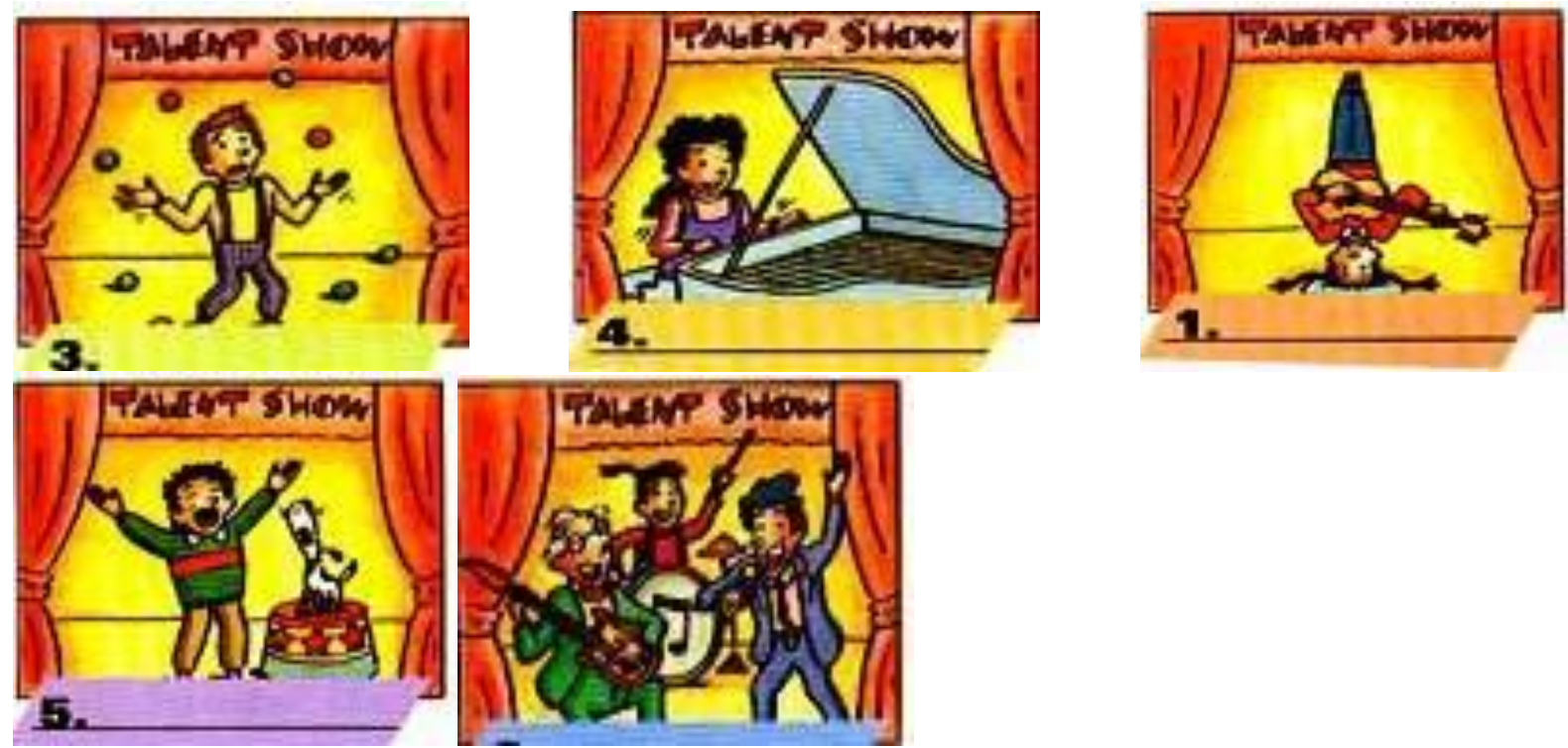

Eliza Vera Steve Dennis The Math Teachers

Step1. Looking at those names and predicting who he/she is

(Eliza is a girl's name, it maybe match with picture 1 or picture 4)

Step2. Discussing and replying the following questions 
Q: In the picture1, what is she doing?

A: She is playing the guitar upside down.

Step3. Listening to the tape and matching the pictures with the names

Step4. Reporting the results

( Picture 1 is Vera who is playing the guitar upside down.)

\subsubsection{Post-listening Step}

This stage is final part of listening which plays an important role in combining the listening materials with the actual situation of the life. It definitely simulates students' interest in communicating with new knowledge and new theme. Simultaneously, in this process, the extension of task can help students consolidate listening achievements and enrich their speaking, reading and writing skills. This process reflects the communicative principles whose ultimate goal is to conduct learners realize the knowledge constructions of the English language to achieve their own language input and output.

There are a few tasks that teachers may do after finishing listening to a text. Firstly, discussing the reactions to the content of the listening to solve some problems in acquiring new language points. Secondly, encouraging students to provoke questions and discussing to reply them. Thirdly, it is commonly used in the listening class to set students to work in pairs or in groups to create dialogues or conversations based on the listening text. And at last, reading or writing activities may be assigned to students based on what they listened, and is also an usual task.

\subsubsection{Sample Teaching of TBA}

\section{Designing}

Topic: How often do you exercise? (1a to 1e in Section B of Unit 2 of New Standard English Textbook, Junior English Student's Book for Grade Eight, China)

\section{Teaching Goals:}

Listening: To understand the requirement of healthy daily habit and recognize the adverbs of frequency.

Speaking: To talk about eating habits with given information.

Reading: To get information from an interview about Tina and Bill.

Writing: To write a short passage about daily habits.

\section{Teaching Points:}

Topic: How to describe and ask about daily habits?

Key vocabulary: junk food, fruit, sleep, milk, vegetables, coffee, want sb.to do, be good for

Key sentence structure: How often do you...?

How many hours do you...?

I do something every day/twice a week/ four times a day.

\section{Procedures:}

\section{Step1: Pre-listening}

Task 1: Predicting the topic of the section

The teacher shows a pyramid of food and ask students to recognize what they are in the picture.

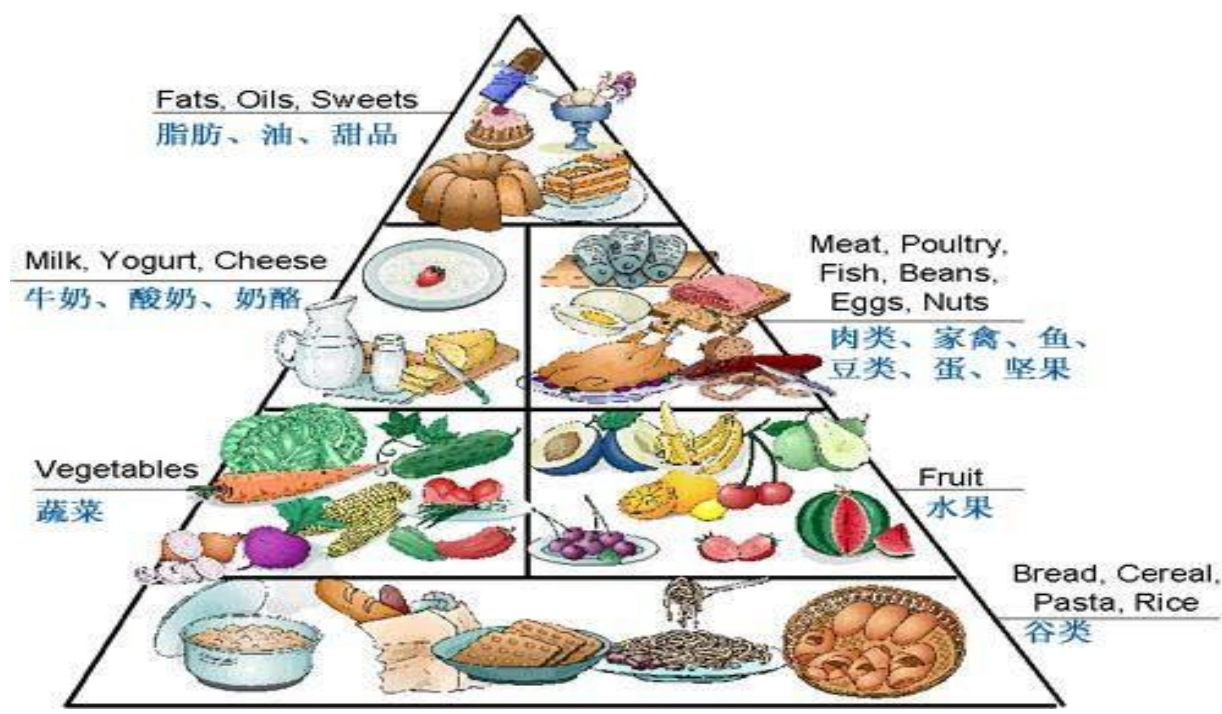


Task 2: Having a discussion

Next the teacher shows the topic of this class and let students discuss what they always do to keep healthy and what is unhealthy for the body in their groups. Then, each group presents their opinions in front of the whole class.

Possible answers:

"Eating junk food and drinking coffee are unhealthy for our health."

"I think good sleep in every night is very important."

"Having a breakfast is healthy."

"Eating more fruit and vegetables plays an necessary role in our eating habits."

This pre-activity offers students an opportunity to find out the class theme and to be familiar with the related materials in upcoming listening text.

\section{Step2: While-listening}

Task 1: Listen and number the pictures

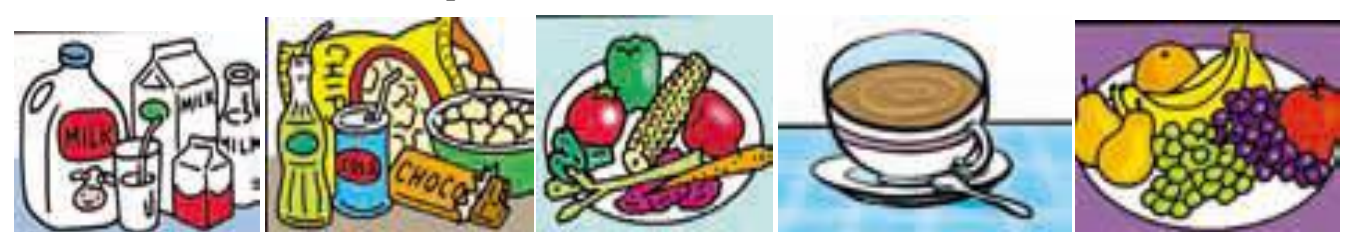

a

b

c

d

e

Task 2: Match the pictures with the expressions

1. junk food ( ) 2. coffee ( ) 3. fruit ( ) 4.milk ( ) 5.vegetables ( )

Task 3: Listen and circle the answer to each question

1. Does Tina have good habits? Yes. No. I don't know.

2. Does Bill have good habits? Yes. No. I don't know.

Task 4: Listen again. Fill in the blanks in the survey.

Questions :

Tina
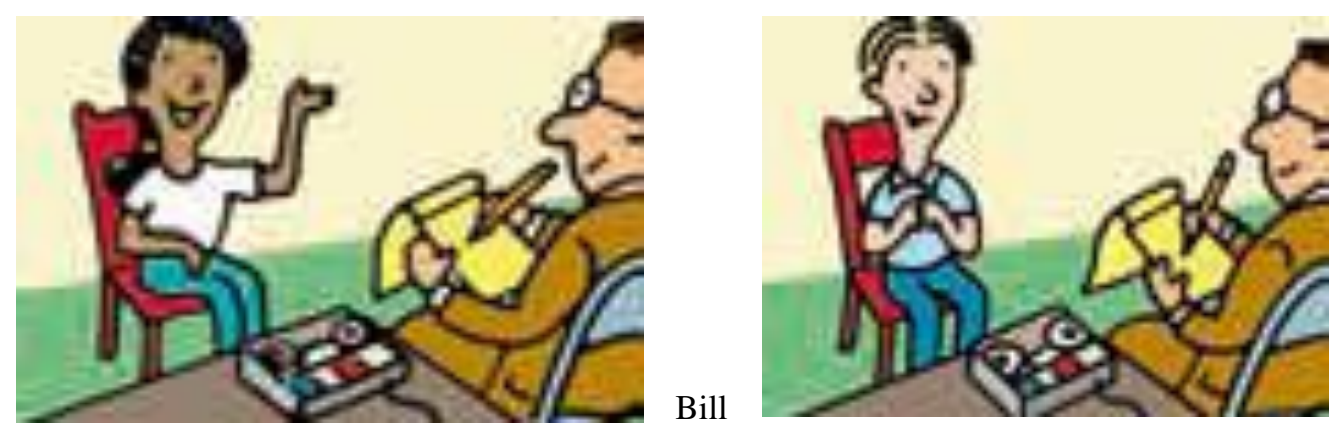

1. How often do you exercise?

2. How often do you eat fruit?

3. How many hours do you sleep every night?

4. How often do you drink milk?

5. How often do you eat junk food?

6. How often do you drink coffee?

This while-listening activities provides practice in understanding the target language in limited context.

\section{Step3: Post-listening}

The following tasks are designed in order to achieve the teaching aims and demands.

Task 1: Complete the sentences in the dialogues and read it together
A: How often do you (喝牛奶), Liu Fang?
B: I drink milk (每天). 
A: Do you like it?

B: No. But my mother (想让我喝它). She says it (对我的健康有好处).

Task 2: Report the results in 1d

\section{Results:}

1. ___every day

2.___ every day

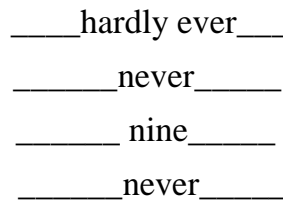

3._nine

4.___ every day

_three or four times a week_

5._two or three times a week_

6. never

four times a day

Student A is the reporter. Student B is Tina or Bill. Ask and answer questions. Then change roles.

A: How often do you exercise?

B: I exercise every day.

A: And how often do you...?

Task 3: Make a conversation by using what you learned in this unit

Possible answers:

A: How often do you drink coffee?

B: I drink it once a day. I like it but I know it may be unhealthy. And I will try my best to drink less.

A: Yes, I agree with you.

B: How many hours do you sleep every night?

A: Nine hours. I believe enough sleep can make us do better in the next day.

\section{Step 4: Homework}

Homework should help train their ability to use what they learned in the class and summarize the learning method by themselves. In this class, the students are asked to write a composition about their habits in daily life.

\section{Data Analysis}

\subsection{Analysis of the Questionnaire Survey}

74 questionnaire survey papers were handed out to the subjects on Dec.10, 2014. After checking, all of them can be used for analysis. In each chart, A rate means the percentage of the participants who choose A in each item. Because A represents a rather positive situation, we will mainly analyze the A rate to show the difference between the experimental group (EG) and the control group (CG).

4.1.1 Comparative Analysis of the Pre-questionnaire

Table 4.1 Comparison of Learners' Interest and Skill in English Listening between experimental group (EG) and control group (CG) before the Experiment

\begin{tabular}{llll}
\hline Question & $\begin{array}{l}\text { A rate of } \\
\text { EG }\end{array}$ & $\begin{array}{l}\text { A rate of } \\
\text { CG }\end{array}$ & Difference in A rate \\
\hline No.1 & $54.0 \%$ & $45.9 \%$ & $8.1 \%$ \\
No.2 & $86.5 \%$ & $81.1 \%$ & $5.4 \%$ \\
No.3 & $21.6 \%$ & $27.0 \%$ & $-7.4 \%$ \\
No.4 & $35.1 \%$ & $27.0 \%$ & $7.9 \%$ \\
No.5 & $40.5 \%$ & $54.1 \%$ & $-13.6 \%$ \\
No.6 & $81.1 \%$ & $75.7 \%$ & $5.4 \%$ \\
No.7 & $13.5 \%$ & $21.6 \%$ & $-8.1 \%$ \\
No.8 & $62.2 \%$ & $67.6 \%$ & $-5.4 \%$ \\
No.9 & $24.3 \%$ & $27.0 \%$ & $-2.7 \%$ \\
No.10 & $10.8 \%$ & $13.5 \%$ & $-2.7 \%$ \\
\hline
\end{tabular}

Table 4.1 reveals that before the experiment the difference is not too great, except for Q 5. From Q 1 and Q 2, we can see that each group has a great interest in English and improving their listening skills. But according to Q 3, only one fifth of them show great confidence in learning English well, the result of the control group (CG) being better than the experimental group (EG). They are not interested in practicing listening in their free time. On the basis of the other four items, it is obvious that most of them recognize the importance of acquiring the learning strategies. However, they are 
not good at applying those necessary strategies. Besides, we can see that when they are listening, the majority of them are worried, both in the experimental group (EG) and the control group (CG). So it is easy to conclude that they truly worry about listening. From Q 10, a few students would like to do some English activities at home like communicating in both groups. According to the chart, it shows that the situation of the experimental group (EG) is slightly worse than that of the control group (CG) in some respects.

4.1.2 Comparative Analysis of the Post-questionnaire

Table 4.2 Results of Questionnaire Survey on Learning Interest of the experimental group (EG) and the control group (CG) Conducted at the End of the Experiments

\begin{tabular}{llll}
\hline Question & A rate of EG & A rate of CG & Difference in A rate \\
\hline No.1 & $62.2 \%$ & $45.9 \%$ & $16.3 \%$ \\
\hline No.2 & $86.5 \%$ & $75.7 \%$ & $10.8 \%$ \\
\hline No.3 & $54.0 \%$ & $27.0 \%$ & $27.0 \%$ \\
\hline No.4 & $54.0 \%$ & $40.5 \%$ & $13.5 \%$ \\
\hline
\end{tabular}

Table 4.2 shows the results of the second survey on the same topic after the twelve-week experiment. It indicates that there is a remarkable difference between the experimental group (EG) and the control group (CG) after the experiment. (see Table 4.3)

Table 4.3 Detailed Comparison of Interest between the experimental group (EG) and the control group (CG)

\begin{tabular}{llllll}
\hline \multicolumn{2}{l}{ A rate of EG } & \multicolumn{3}{l}{ A rate of CG } & \multicolumn{2}{l}{ Difference in A rate } \\
\hline Before & After & Before & After & Before & After \\
\hline $54.0 \%$ & $62.2 \%$ & $45.9 \%$ & $45.9 \%$ & $8.1 \%$ & $16.3 \%$ \\
\hline $86.5 \%$ & $86.5 \%$ & $81.1 \%$ & $75.7 \%$ & $5.4 \%$ & $10.8 \%$ \\
\hline $21.6 \%$ & $54.0 \%$ & $27.0 \%$ & $27.0 \%$ & $-7.4 \%$ & $27.0 \%$ \\
\hline $35.1 \%$ & $54.0 \%$ & $27.0 \%$ & $40.5 \%$ & $7.9 \%$ & $13.5 \%$ \\
\hline
\end{tabular}

From Table 4.3, people in the experimental group (EG) are more interested in English listening than those in the control group (CG). Maybe the implementation of the task-based approach in the listening class can improve students' interest in learning English listening.

Table 4.4 The Effect of the Task-based Approach Investigation after the Experiment

\begin{tabular}{lllll}
\hline Question & A & B & C & A rate \\
\hline No.5 & 24 & 9 & 4 & $64.9 \%$ \\
\hline No.6 & 22 & 8 & 7 & $59.5 \%$ \\
\hline No.7 & 19 & 12 & 6 & $51.4 \%$ \\
\hline No.8 & 24 & 7 & 6 & $64.9 \%$ \\
\hline No.9 & 25 & 6 & 6 & $67.6 \%$ \\
\hline No.10 & 23 & 5 & 9 & $62.2 \%$ \\
\hline
\end{tabular}

We can see from the above table that more than $50 \%$ of the students are satisfied with TBA which helped their English listening grades and English listening levels. With the help of this approach, most students have grasped language knowledge and communicative skills from their group activities.

From Table 4.1 to Table 4.2, we find that students in the control group do well in learning English listening comprehension at the beginning. However, after three months, the students in the experimental group are more interested in learning English learning. The change in the control group is not obvious. Based on those graphs, we can conclude that the Task-based approach is useful to improve students' interest.

\subsection{Analysis of the Two Tests}

The full score for listening comprehension is twenty-five points for each paper. The results of the whole class can be seen in Appendix III.

4.2.1 Analysis of the Pre-test Results

Table 4.5 Comparison of the Two Groups' Grades in the Listening Comprehension of the Pre-test

\begin{tabular}{lllll}
\hline Class & Number & Mean & SD & Z \\
\hline EG & 37 & 19.2 & 3.70 & 0.93 \\
\cline { 1 - 3 } CG & 37 & 19.6 & 3.17 & \\
\hline
\end{tabular}


From Table 4.5, we can see that experimental group (EG) is a little lower than the control group (CG). The standard variation of the experimental group (EG) is 3.70 and that of the control group (CG) is $3.17, Z=0.93<1.96$. That means there is no clear difference between the two classes before the pre-test.

4.2.2 Analysis of the Post-test Results

Table 4.6 Comparison of the Two Groups' Grades in Listening Comprehension of Post-test

\begin{tabular}{lllll}
\hline Class & Number & Mean & SD & Z \\
\cline { 1 - 3 } EG & 37 & 21.80 & 3.40 & \multirow{2}{*}{3.21} \\
\cline { 1 - 3 } CG & 37 & 20.40 & 3.64 &
\end{tabular}

From Table 4.6, we can know that there is a difference between the experimental group (EG) and the control group (CG). The standard variation of the experimental group is 3.4 and that of the control group is $3.64, \mathrm{Z}=3.21>1.96$. The data shows that the experiment has achieved the great effect.

After analyzing the two tests, we can find that the students in the EG do better than those in the CG. Their grades have made great progress through counting standard deviation (SD). Thus, we can know that the Task-based approach is helpful to improve students' strategies.

\section{Conclusion}

The result is consistent with the hypothesis.The analysis clearly indicates that the task-based approach has a positive effect on students' interest in studying listening and their levels of English listening. In the course of accomplishing tasks, students are treated as the center. After three months' experiment, they also feel better and more confident in communicating and listening in public. Therefore, the task-based Approach is effective in English listening class. So the approach can be used in English listening teaching in junior high school.

When using the teaching method, the teacher can take the following measures (Mo, 2013). On the one hand, teachers should design tasks and language environment authentically. As a result, learner can master language actively and autonomously in a real situation. Besides, teachers should not just be satisfied with the form of listening in the textbook. It's necessary to take much more games, stories and other activities to make the listening class more interesting. On the other hand, teachers must not only learn to inspire students' interest in English listening but also help them remain it. Actually, from the whole experiment, we can easily see that at least a half of the students are interested in learning English, but they just feel that it is so hard to learn it well. Thus, teachers should focus on the importance of leading in and creating an atmosphere where they are willing to express themselves. In all, it is vital to instruct students to gain the competence of using language.

\section{References}

Jiao, J. (2014). A Study on the Application of Task-based Approach to English Listening Teaching in Middle Schools[D]. Tianjin: Tianjin Normal University.

Mo, Zh. (2013). Application of Task-based Approach in English Listening Teaching for Senior Middle Schools[D]. Guangxi: Guangxi University.

Nunan, D. (1989). Designing Tasks for the Communicative Classroom [M]. New York: Cambridge University Press.

Skehan, P. A. (1998). Cognitive Approach to Language Learning [M]. Oxford: Oxford University Press.

Underwood, M. (1989). Teaching Listening[M]. London: Longman.

Willis, J. A. (1996). Framework for Task Based Learning[M]. London: Longman.

Ministry of Education in China. Go For It. Beijing: People's Education Press, 2013.

\section{Appendixes}

\section{Appendix I A Questionnaire about Interest and Method in English listening learning}

Dear participants:

Hello! First, I appreciate for your cooperation to fill in the blanks about your interest and strategy in English listening learning. Then, please finish the questionnaire alone. And you should pay attention to just choose one for each question. Thank you again!

\section{No.1 You like English listening.}

$\begin{array}{llll}\text { A. agree } & \text { B. neutral } & \text { C. disagree }\end{array}$

No.2 You want to improve your English level.
A. agree
B. neutral
C. disagree

No.3 You have confident in learning English listening well. 
$\begin{array}{ll}\text { A. agree B. neutral C. disagree } & 0\end{array}$

No.4 You listen to English.

A. often B. sometimes C. never

No.5 Which method is the best in your mind?
A. doing listening exercises
B. acquiring listening strategies
C. reciting vocabularies

No.6 Listening strategies is helpful to improve listening comprehension ability.
A. agree
B. neutral
C. disagree

No.7 How is your listening skill?
A. good
B. just so-so
C. bad

No.8 You use your listening skill in listening.
A. often
B. sometimes
C. never

No.9 You feel calm in doing listening comprehension.
A. agree
B. neutral
C. disagree

No.10 You communicate with your classmates in English after class.

A. often B. sometimes C. never

\section{Appendix II A Questionnaire about Task-based Approach in Listening Teaching}

Dear participants:

Hello! First, I appreciate for your cooperation to fill in the blanks about your interest and strategy in English listening learning. Then, please finish the questionnaire alone. And you should pay attention to just choose one for each question. Thank you again!

No.1 You like English listening.
A. agree
B. neutral
C. disagree

No.2 You want to improve your English level.
A. agree
B. neutral
C. disagree

No.3 You have confident in learning English listening well.
A. agree
B. neutral
C. disagree

No.4 You listen to English.

A. often B. sometimes C. never

No.5 With the help of task-based approach teaching, you think that your listening scores increase.
A. agree
B. neutral
C. disagree

No.6 With the help of task-based approach teaching, you think that your listening level is improved.
A. agree
B. neutral
C. disagree

No.7 You are satisfied with TBA teaching method.
A. agree
B. neutral
C. disagree

No.8 With the help of task-based approach teaching, you think that you acquire more listening strategies.
A. agree
B. neutral
C. disagree

No.9 TBA teaching method broaden your horizons.
A. agree
B. neutral
C. disagree

No.10 With the help of task-based approach teaching, you have more communication with your classmates in English after class.
A. agree
B. neutral
C. Disagree 


\section{Appendix III Students' Scores Records}

\begin{tabular}{|c|c|c|c|c|c|}
\hline \multicolumn{6}{|l|}{ Pre-test } \\
\hline \multicolumn{3}{|c|}{ The Experimental Group } & \multicolumn{3}{|c|}{ The Control Group } \\
\hline Number & Scores & Listening Scores & Number & Scores & Listening Scores \\
\hline Student1 & 84.0 & 20 & Student1 & 95.0 & 21 \\
\hline Student2 & 85.0 & 19 & Student2 & 80.0 & 19 \\
\hline Student3 & 102.5 & 21 & Student3 & 80.0 & 19 \\
\hline Student4 & 95.0 & 22 & Student4 & 90.0 & 21 \\
\hline Student5 & 90.5 & 22 & Student5 & 95.0 & 21 \\
\hline Student6 & 94.5 & 22 & Student6 & 108.0 & 24 \\
\hline Student7 & 102.0 & 22 & Student7 & 90.0 & 21 \\
\hline Student8 & 70.5 & 16 & Student 8 & 93.0 & 20 \\
\hline Student9 & 76.0 & 20 & Student9 & 82.0 & 19 \\
\hline Student10 & 38.0 & 14 & Student10 & 38.0 & 11 \\
\hline Student11 & 83.0 & 21 & Student11 & 97.0 & 22 \\
\hline Student12 & 81.5 & 22 & Student 12 & 108.0 & 24 \\
\hline Student13 & 77.5 & 20 & Student13 & 99.0 & 22 \\
\hline Student14 & 42.5 & 13 & Student14 & 52.0 & 17 \\
\hline Student15 & 102.0 & 23 & Student 15 & 104.0 & 22 \\
\hline Student16 & 43.0 & 15 & Student 16 & 82.0 & 19 \\
\hline Student17 & 111.5 & 23 & Student17 & 100.0 & 22 \\
\hline Student18 & 95.0 & 21 & Student18 & 75.0 & 19 \\
\hline Student19 & 84.5 & 19 & Student19 & 45.0 & 15 \\
\hline Student20 & 77.0 & 19 & Student20 & 75.0 & 19 \\
\hline Student 21 & 16.0 & 6 & Student21 & 35.0 & 10 \\
\hline Student 22 & 88.5 & 20 & Student22 & 93.0 & 19 \\
\hline Student23 & 107.0 & 24 & Student 23 & 65.0 & 18 \\
\hline Student24 & 103.5 & 21 & Student24 & 80.0 & 19 \\
\hline Student25 & 95.0 & 17 & Student25 & 70.0 & 19 \\
\hline Student26 & 32.0 & 11 & Student26 & 90.0 & 21 \\
\hline Student27 & 62.0 & 17 & Student27 & 81.0 & 19 \\
\hline Student28 & 108.0 & 21 & Student 28 & 75.0 & 19 \\
\hline Student29 & 89.5 & 21 & Student29 & 98.0 & 22 \\
\hline Student 30 & 81.5 & 21 & Student30 & 101.0 & 22 \\
\hline Student 31 & 103.0 & 21 & Student31 & 85.0 & 19 \\
\hline Student32 & 76.5 & 19 & Student 32 & 105.0 & 22 \\
\hline Student33 & 86.0 & 19 & Student 33 & 95.0 & 21 \\
\hline Student34 & 27.0 & 15 & Student34 & 41.0 & 12 \\
\hline Student35 & 98.5 & 21 & Student35 & 92.0 & 22 \\
\hline Student36 & 80.5 & 20 & Student36 & 97.0 & 22 \\
\hline Student 37 & 107.0 & 24 & Student37 & 105.0 & 23 \\
\hline Average & 81 & 19.2 & & 83.7 & 19.6 \\
\hline
\end{tabular}




\begin{tabular}{|c|c|c|c|c|c|}
\hline \multicolumn{6}{|l|}{ Post-test } \\
\hline \multicolumn{3}{|c|}{ The Experimental Group } & \multicolumn{3}{|c|}{ The Control Group } \\
\hline Number & Scores & Listening Scores & Number & Scores & Listening Scores \\
\hline Student1 & 81 & 17 & Student1 & 90.5 & 23 \\
\hline Student2 & 87 & 23 & Student2 & 79.0 & 15 \\
\hline Student3 & 104 & 21 & Student3 & 83.0 & 15 \\
\hline Student4 & 109 & 24 & Student4 & 91.0 & 24 \\
\hline Student5 & 101 & 21 & Student5 & 95.0 & 24 \\
\hline Student6 & 105 & 25 & Student6 & 101.0 & 24 \\
\hline Student7 & 110 & 23 & Student7 & 90.0 & 21 \\
\hline Student8 & 76 & 21 & Student8 & 110.0 & 25 \\
\hline Student9 & 82 & 23 & Student9 & 82.0 & 21 \\
\hline Student 10 & 55 & 18 & Student 10 & 40.0 & 15 \\
\hline Student 11 & 77 & 24 & Student 11 & 97.0 & 23 \\
\hline Student 12 & 97 & 22 & Student12 & 108.0 & 25 \\
\hline Student 13 & 91 & 22 & Student13 & 102.0 & 18 \\
\hline Student 14 & 55 & 11 & Student14 & 49.0 & 14 \\
\hline Student15 & 108 & 23 & Student15 & 104.0 & 25 \\
\hline Student16 & 72 & 21 & Student 16 & 82.0 & 18 \\
\hline Student 17 & 116 & 24 & Student17 & 95.0 & 24 \\
\hline Student 18 & 109 & 25 & Student 18 & 75.0 & 18 \\
\hline Student19 & 99 & 22 & Student19 & 60.5 & 14 \\
\hline Student20 & 87 & 25 & Student20 & 90.0 & 21 \\
\hline Student 21 & 35 & 14 & Student 21 & 35.0 & 14 \\
\hline Student 22 & 97 & 22 & Student22 & 90.0 & 22 \\
\hline Student23 & 111 & 25 & Student 23 & 64.0 & 17 \\
\hline Student24 & 103 & 25 & Student24 & 87.5 & 20 \\
\hline Student25 & 104 & 23 & Student25 & 70.0 & 16 \\
\hline Student26 & 37 & 13 & Student26 & 90.0 & 21 \\
\hline Student27 & 86 & 21 & Student 27 & 89.0 & 19 \\
\hline Student 28 & 112 & 25 & Student 28 & 75.0 & 17 \\
\hline Student29 & 102 & 24 & Student29 & 98.0 & 24 \\
\hline Student30 & 103 & 22 & Student 30 & 110.0 & 25 \\
\hline Student 31 & 101 & 24 & Student 31 & 85.0 & 19 \\
\hline Student 32 & 87 & 21 & Student 32 & 100.0 & 24 \\
\hline Student 33 & 93 & 22 & Student 33 & 95.0 & 22 \\
\hline Student34 & 37 & 17 & Student34 & 60.0 & 18 \\
\hline Student35 & 98 & 24 & Student 35 & 93.0 & 22 \\
\hline Student 36 & 95 & 23 & Student 36 & 97.0 & 23 \\
\hline Student37 & 111 & 25 & Student 37 & 110.0 & 25 \\
\hline Average & 90.1 & 21.8 & & 85.7 & 20.4 \\
\hline
\end{tabular}

